\title{
Michaił Bachtin
}

\section{$<$ Retoryka - o ile jest kłamliwa... $>^{*}$}

Niniejszy tekst został po raz pierwszy opublikowany na podstawie rękopiśmiennych zapisków Bachtina przez W. W. Kożynowa pod tytułem <O lubwi i poznanii $w$ chudoziestwiennom obrazie> („Literaturnaja uczoba” 1992, nr 5-6, s. 153-156, przygot. tekstu W. I. Sławiecki). Obecne wydanie dokonane zostało na podstawie rękopisów zachowanych w Archiwum Bachtina. Tytuł, zgodnie z przyjętą zasadą opatrywania incipitem notatek przez autora niezatytulowanych, pochodzi od redaktorów tomu.

Rękopis Bachtina jest opatrzony datą 12 października 1943 roku. Stanowi on prawdopodobnie material do obszerniejszej rozprawy. Poruszane problemy (eposu i powieści, dialogu, stanowiska autora i jego przewagi nad pozycją bohatera, poetyki i filozofii prozy Gogola i Dostojewskiego) pozwalają przypuszczać, że zapis z 12 października 1943 r. odnosi się bądź do ukończonego wcześniej artykułu o powieści, bądź stanowi szkic do nowej, planowanej pracy.

Historią i teorią powieści Bachtin zajmował się w latach trzydziestych. W 1940 i 1941 roku, na podstawie odczytów wygłoszonych w Instytucie Literatury Światowej i Sztuki 14 października 1940 r. i 24 marca 1941r., przygotował dwa poświęcone tym zagadnieniom artykuły: Slowo $w$ powieści ( $Z$ zagadnień stylistyki powieści) i Powieść jako gatunek literacki. W nieznacznie zmienionych wersjach zostały one opublikowane w Problemach literatury $i$ estetyki - pierwszy jako $Z$ prehistorii slowa w powieści, drugi - Epos a powieść (O metodologii badania powieści).

Odczyty 1940 i 1941 roku są ze sobą ściśle powiązane: w obydwu rozpatrywane są problemy pochodzenia i historii powieści, w obydwu śmiech i wielojęzyczność analizowane są jako najważniejsze przesłanki genezy powieściowego słowa. Jednak w sposobie postawienia problemu eposu i powieści, pamięci i poznania oraz filozoficznych aspektów teorii powieści, komentowany tekst bliższy jest odczytowi z 1941 roku. O ile bowiem analiza filozoficznych problemów teorii powieści wykraczała w zasadzie poza zakres rozprawy Epos a powieść..., to prezentowany tekst został w większej części poświęcony epistemologicznym problemom teorii gatunku: zagadnieniom artystycznego poznania ,ja" i „innego”, świadomości tworzącej obrazy „ja" i „innego”, niezbieżności obrazów ,ja” dla siebie i ,ja” dla innego, zewnętrznego usytuowania ,ja” wobec „innego" przy tworzeniu jego obrazu i niewymienności obu pozycji wobec aksjologicznego niedomiaru pierwszej i aksjologicznej przewagi drugiej.

Przekład na podstawie: Michail M. Bachtin, Sobranije soczinienij, t. 5 - Raboty 1940 - naczala 1960 godow, redaktorzy tomu: S. G. Boczarow i L. A. Gogotiszwil, Moskwa 1996, „Russkije Słowari”, s. 63-70. Informacje o tekście stanowią skrót szczegółowego, pieczołowitego komentarza, jakim opatrzyła edycję redakcja rosyjska. Nawiasy ostrokątne < > pochodza od redakcji rosyjskiej i oznaczają albo miejsca w rękopisie nieodczytywalne, albo wprowadzone przez redaktorów (jak powyższy tytuł). 
Retoryka, o ile jest kłamliwa, dąży do wywołania strachu lub nadziei. Takie nastawienie należy do istoty słowa retorycznego (podkreślała je już retoryka antyczna). Natomiast celem zarówno sztuki (prawdziwej), jak poznania, jest wyzwolenie od tych uczuć. Inaczej wyzwala tragedia, inaczej-śmiech.

Połączenie pochwały i obelgi jako wyższy stopień artystycznego obiektywizmu (głos całości).

Kult wprowadzenia zmarłego do grona przodków, opisany przez Polibiusza. Współrzędne obrazu epickiego; pakt z przeszłością, w której umieszczane jest centrum wartości.

Epos przenosi wszystkie istotne wartości na daleki plan czasu przeszłego; z punktu widzenia eposu wszelka przyszłość (potomkowie, współcześni) oznacza regres („- Oj tak! I ludzie też przed laty, Nie tacy byli: same chwaty!"1).

W eposie wszystko, co najlepsze, znajduje się w polu przedstawienia; w powieści natomiast, wszystko, co dobre, lokuje się poza światem przedstawionym, w przyszłości. W świecie przedstawionym pojawia się jedynie potrzeba, pragnienie tej przyszłości.

Każda rzecz nosi dwie nazwy - wysoką i niską. Przezwisko. Podwójne imiona w Onieginie: Tatiana, sentymentalne imiona nadane przez Tatianę wiejskim babom w domu Łariny. Dwojakie nazywanie świata, dwa opisujące jeden i ten sam świat języki.

Pierwszy rozdzial Oniegina. Próba analizy gatunkowej (jako uzupełnienie do artykułu). Konieczność przejścia od drugiej nazwy przedmiotu lub postaci do familiarnych warstw różnojęzyczności.

Problem dialogu. Rola czasu w dialogu. Spór czasów.

Tradycja i symbole (u Dostojewskiego) i ich świadome stosowanie do współczesnej rzeczywistości. Czy to system, czy też czysty przypadek i naciąganie faktów w stylu solarnych objaśnień legendy Napoleona. To samo można znaleźć w dowolnym innym materiale.

U podstaw - rdzennie powieściowe naruszenie tabu (profanacja). Otwartość, autodemaskacja, zniewaga. Nie zwykły bieg życia, lecz wiara w cud, w możliwość radykalnej zmiany. Akcja rozgrywa się w punktach chronotopowych, wyłączonych z powszedniego życiowego procesu i z przestrzeni, w ktorej się on rozgrywa, w punktach ekscentrycznych, infernalnych, rajskich (objawienie, błogość, hosanna) i czyśćcowych. Jak wygląda scen a zdarzenia u Dostojewskiego. Zgłębić tradycyjność jej organizacji. Organizacja (topograficzna) sceny antycznej tragedii bądź komedii, sceny misteryjnej, cyrkowej areny, świątyni, sceny jarmarcznej. Dostojewski

\footnotetext{
${ }^{1}$ M. Lermontow, Borodino, przeł. L. Podhorski-Okołów, w: tegoż, Wiersze i poematy, Warszawa 1980, s. 115.
} 
nie umiał radzić sobie $\mathrm{z}$ wielkimi wymiarami czasu (biograficznego, historycznego), nie powiodła mu się więc próba stworzenia powieści biograficznej; również ze wszystkich jego powieści nie da się złożyć ani powieści biograficznej, ani historycznej, ani powieści pokoleniowej. Punktów ekscentrycznych, kryzysowych, infernalnych nie można przecież połączyć ciągłą linią biografii ani historii. $Z$ reguły na scenie Dostojewskiego zwykły bieg życia, mierzony rytmem upływającego czasu, zagęszcza się i kondensuje. Życie wypada niejako ze swoich kolein, skupiając się w punktach nieciagłości i w zagięciach czasu. Człowiek umiera, by narodzić się jako ktoś zupełnie inny, nowy, bez jakiegokolwiek pokrewieństwa ze sobą minionym. Kontynuacja powieści o nim byłaby całkiem inną powieścią, z innym bohaterem, noszącym inne imię. Sen i satyra oniryczna (jedna $\mathrm{z}$ odmian satyry menipejskiej).

Rozpaczliwa niezgoda na miejsce zajmowane w życiu staje się warunkiem życia. Miejsce to nie jest traktowane nawet jako punkt wyjścia do odrodzenia. Bohater nie ma rodziny, określonej przynależności społecznej, nie jest nigdzie zakorzeniony.

Punkt widzenia z zewnątrz, jego przewaga i ograniczenia. Punkt oglądu siebie samego od wewnątrz. Miejsce, w którym pozycje te z przyczyn zasadniczych nie mogą się pokrywać ani utożsamiać. To właśnie w miejscu ich rozchodzenia, nie zaś nakładania się (które podmiot osiaga niezależnie od obserwacji z zewnątrz czy od wewnątrz) rozgrywają się zdarzenia. Odwieczny konflikt w procesie samopoznania ,ja" i „innego".

Odpowiedzialność i wina za świat u Gogola. Kosmiczna groteskowość strasznej zemsty. Konfesyjno-autobiograficzny aspekt twórczości Gogola. Jej wymiar profetyczny.

Element przemocy w poznaniu i w formie artystycznej. Wprost proporcjonalny do niego element kłamstwa. Słowo przeraża, obiecuje, rozbudza nadzieje, wysławia l u b potępia (połączenie pochwały i obelgi neutralizuje kłamstwo). Wypowiedzi władców o samych sobie. Przemoc w akcie poznania przedmiotu. Poprzedzająca je przesłanka - uśmiercenie przedmiotu; cel - podporządkowanie świata (przekształcenie świata $\mathrm{w}$ pochłaniany przedmiot). Uśmiercająca siła obrazu artystycznego: zajść przedstawiany przedmiot od strony przyszłości, wyczerpać go, pozbawiając tym samym otwartej przyszłości, ukazać wszystkie jego granice (i wewnętrzne, i zewnętrzne), zamykając jakąkolwiek drogę wyjścia $z$ tego zamknięcia - oto on sam, caly, obecny tu i nigdzie indziej; a skoro jest tutaj, definitywnie skończony, to znaczy, że jest martwy i można go pochlonaḉ; usunięty poza toczące się życie, staje się przedmiotem potencjalnego użytku, nie uczestniczy samodzielnie w zdarzeniu życia, nie rozwija się wraz z nim; wypowiedział już ostatnie słowo, jest pozbawiony wewnętrznego, tętniącego jądra, wewnętrznej nieskończoności. Odebrano mu wolność, akt poznania 
chce go osaczyć go ze wszystkich stron, pozbawić niedefinitywności, a więc także wolności, przyszłego czasu i znaczenia, nierozstrzygalności i wewnętrznej prawdy. Tak samo działa obraz artystyczny - nie wskrzesza ani nie uwiecznia przedmiotu dla niego samego, lecz dla siebie.

To wszakże dopiero jedna strona medalu. Druga - przedmiotowi nakazuje się $\mathrm{z}$ zewnątrz, czym/kim powinien być, a tym samym pozbawia się go prawa do swobodnego samookreślenia. Przyszpilony określeniem zastyga $\mathrm{w}$ nim. Przemoc w obrazie organicznie lączy się ze strachem i zastraszaniem. Mówca (twórca) nie uśmiecha się, jest poważny. Powaga implikuje wymaganie, groźbę, presję. Bądź tym, kim powinieneś być (powinność narzucona $z$ zewnątrz). Wieczne zagrożenie dniem dzisiejszym dla wszystkiego, co pragnie wyrwać się poza jego granice: co niewczesne, uchodzi za zbędne, niezdolne do spełnienia wyznaczonych zadań...

Tymczasem właśnie to, co najbardziej nie współbrzmi ze swoim czasem, bywa najbardziej wolne, prawdziwe, bezinteresowne. Teraźniejszość nie może nie kłamać. Im więcej w niej żelaza i krwi, tym mocniej tężeje w wiekach przygniatającym ciężarem historii. Dzień obecny, dopuszczając się przemocy, zawsze podaje się za sługę przyszłości. Ale ta przyszłość jest jedynie kontynuacją, skutkiem ucisku, nie zaś wyjściem na wolność i przeobrażeniem. Tu przemówić powinna wewnętrzna wolność i niewyczerpywalność przedmiotu. Tymczasem rozpoznawane są jedynie konieczności rządzące światem, tj. to, co zostało już pozbawione wolności, co może być wykorzystane, spożytkowane, użyte, to, co czysto instrumentalne. Taka postawa jest usprawiedliwiona, dopóki nie przekracza granic, nie przeradza się $\mathrm{w}$ gwałt nad życiem.

Tylko miłość zdolna jest dostrzec i ukazać wewnętrzną wolność przedmiotu. Wprawdzie jest jeszcze poważna, ale już rozjaśnia się uśmiechem, a uśmiech i radość zawsze przezwyciężają powagę, zacierają surowe rysy jej oblicza, łagodzą ton przestrogi. Tylko w atmosferze miłości przedmiot wyjawia swą absolutną bezinteresowność. Miłość bowiem nie narusza go, lecz mu towarzyszy, obłaskawia i łagodzi jego granice, które dzięki temu nabierają nowego znaczenia. Miłość nie mówi o przedmiocie pod jego nieobecność, ale rozmawia z nim o nim samym. Słowo-przemoc zakłada natomiast przedmiot nieobecny i milczący, głuchy i niemy, nie zwraca się do niego i nie potrzebuje jego zgody, jest odgórne. Słowo o przedmiocie nigdy nie pokrywà się z jego własnym słowem o sobie-dla-siebie. Daje mu określenia, z którymi on sam nigdy nie będzie mógł pogodzić się wewnętrznie. Owo słowo-przemoc (i kłamstwo) zbiega się z niezliczonymi osobistymi interesami twórcy, które mącą czystość jego intencji - żądzą sukcesu, zdobycia wpływów i uznania (nie dla słowa jednak, lecz dla siebie samego), dążeniem do zdominowania i zinstrumentalizowania przedmiotu. To 
słowo pragnie definiować i wywierać presję z zewnątrz. Już sama postawa pewności jest tożsama z przemocą. Świat dusi się we wlasnym sosie i dlatego konieczny jest nieustanny dopływ $z$ innych światów.

Wypowiedziane dotychczas słowo było wyjątkowo naiwne, a mówcy jak dzieci - próżni, zarozumiali i ufni. Słowo nie wie, komu służy, wyłania się z mroku, nie znając swych korzeni. Jego powaga wiąże się ze strachem i przemoca. Człowiek prawdziwie dobry, bezinteresowny i kochający zachowywał dotąd milczenie, realizując się w życiu codziennym, nie imając się słowa zorganizowanego, zarażonego kłamstwem i przemocą. Nie był pisarzem. Dobroć i miłość, o ile pisarz je odczuwa, wypełniają słowo ironią, niepewnością, wstydliwością (wstyd powagi). Słowo było silniejsze od człowieka, który, znajdując się w jego mocy, nie mógł brać za nie odpowiedzialności. Mógł być jedynie heroldem cudzej prawdy, pozostając w jej absolutnej władzy. Nie czuł jednak jej racji ani legitymizacji. Chłód i obcość prawdy. Dobru i miłości, radości i łasce udawało się do niej przeniknąć jedynie przemytem. Nikt jeszcze nie słyszał o ogrzewającej prawdzie, istniało tylko zagrzewające kłamstwo. Proces twórczy jest zawsze aktem przemocy, przemocy prawdy nad duszą. Prawda nigdy jeszcze nie sprzymierzyła się z człowiekiem, nie przychodziła $z$ jego wnętrza, lecz z zewnątrz, stawała się obsesją. Była objawieniem, lecz nie objawiała, zawsze coś przemilczała, otaczała się tajemnicą, a więc również działała przemocą. Siłą pokonywała człowieka, który nie czuł się jej synem. Kto temu winien - prawda czy człowiek. Człowiek przyjmował prawdę o sobie jako siłę niszczycielską. Łaska zawsze spływała na niego z zewnątrz.

Sam przedmiot nie współtworzy swego obrazu. Obraz spada na niego jak cios bądź dar, ale dar z zewnątrz, zawsze fałszywy, obłudny, pochlebczy. Obraz wysławiający przedmiot łączy się z kłamstwem przedmiotu o sobie samym: ukrywa i wyolbrzymia. Zasadnicza odgórność obrazu. Obraz zasłania przedmiot, ignorując tym samym jego zdolność do przemiany, do bycia innym. Nie spotykają się w nim ani nie łączą głos przedmiotu i głos mówiącego o nim. Przedmiot wyrywa się poza własne granice, żyje wiarą w cud nieoczekiwanego przeobrażenia. Obraz natomiast zmusza go do tożsamości z sobą samym, wtłacza w beznadziejność definitywności i finalności. Obraz bezwzględnie wykorzystuje uprzywilejowanie stanowiska z zewnątrz. Na pierwszy plan wysuwa kark, uszy, plecy przedmiotu - to znaczy jego granice. W obrazie żywa jest jeszcze magiczna moc nad przedmiotem. Residua przemocy. Konieczność przeobrażenia w sens. Desubstancjalizacja dzięki sensowi i miłości.

Nastawienie na niezniszczalność przedmiotu, a nie na jego zniszczalność-unicestwialność. Czysta samoekspresja, czyste sam na sam ze sobą, bez zewnętrznego punktu widzenia, jeden głos, samotny wgląd w siebie, 
modlitwa. Samotny głos czystej autoekspresji i odgórny obraz nigdy się nie spotykają (brak płaszczyzny dla takiego spotkania), mogą co najwyżej naiwnie się pomieszać (przyglądanie się sobie w lustrze). Nieskończoność wewnętrznej wartości człowieka i finalność jego zewnętrznego, incydentalnego, odgórnego obrazu w ,innym"; średnia między nimi to mierny <> obrazek siebie samego. Wpisać siebie w swój odgórny obraz, stłumić samoświadomość niewyczerpywalności własnej wartości, stężeć w takim obrazie i stać się przedmiotem gotowym do pochłonięcia i wykorzystania. Wiara w miłość, zdolną sprostać wewnętrznej nieskończoności. Nauka pozytywna tworzy odgórny (unicestwiający) obraz świata, dążąc do zamknięcia tworzącego się życia i znaczenia. W takim obrazie brak jednak głosu samego świata; zamiast jego przemawiającego oblicza, jest tylko kark i plecy. Poszukiwanie nowej płaszczyzny umożliwiającej spotkanie ,ja" i ,innego", stworzenie obrazu człowieka bez ignorowania historii i historyczności samego obrazu.

Wiara w adekwatność odwzorowania siebie w najwyższym „innym”. Bóg jest jednocześnie i we mnie, i poza mną, a zatem mój obraz siebie samego w pełni odwzorowuje moją wewnętrzną nieskończoność i niedefinitywność, w pełni zawiera się w nim także niewspółobecność Boga.

Co we mnie może być rozważone i ocenione tylko $\mathrm{z}$ punktu widzenia "innego" (szeroko rozumiany wygląd zewnętrzny, powierzchowność, habitus duszy, całość życia, dostępna jedynie cudzej pamięci o mnie).

Miłość do siebie, użalanie się nad sobą, zachwycanie się sobą mają złożony i specyficzny charakter. Wszystkie elementy samooceny i samouwielbienia ( $\mathrm{z}$ wyjątkiem samozachowawczych) uzurpują sobie prawo do zajęcia miejsca „innego", do jego punktu widzenia. To nie ja oceniam pozytywnie siebie z zewnątrz, lecz wymagam tego od "innego", stawiam siebie w jego pozycji. Siedzę zawsze na dwóch stołkach. Swój obraz tworzę (uświadamiam sobie siebie) jednocześnie i z własnego, i z cudzego stanowiska.

Pozycja z zewnątrz i jej dominacja. Wykorzystanie wszystkiego, czego "inny” z zasady nie może wiedzieć o sobie samym ani w sobie dojrzeć. Wszystkie takie elementy pełnią prymarnie funkcję definiującą. Możliwość obiektywnego i neutralnego samopoznania i samooceny, niezależnie od punktu widzenia „ja” czy „innego”. To właśnie umartwiający odgórny obraz, pozbawiony dialogiczności i niedefinitywności. Całość definitywnie zamknięta jest zawsze odgórna. Nie da się jej doświadczyć od wewnątrz, lecz tylko z zewnątrz. Finalizm stanowiska zewnętrznego.

Obraz ludzkiej duszy. Mogą się w nim znaleźć tylko jej elementy wyrażalne, zdolne stać się słowem, tj. jej skierowanie poza siebie, eksterioryzacja. Człowiek jako przedmiot artystycznego przedstawienia. Artystyczne przedstawienie człowieka, jego formy i granice. 
Otoczenie i horyzont.

Stopień najwyższy. Jego aspekt czasowy („pierwszy”) i aksjologiczny ("najlepszy”). Chronotop sceny. Analiza tego chronotopu. Człowiek na scenie (na płótnie, bohater utworu literackiego), jego odseparowanie. Taki człowiek znajduje się $\mathrm{w}$ punkcie skrzyżowania horyzontu $\mathrm{z}$ otoczeniem, wykracza poza siebie, wchodząc $w$ sferę wyrażania. To złożony punkt przecięcia i wzajemnego oddziaływania stref, punktów widzenia, granic.

Obraz człowieka jako najważniejszy obraz w całej literaturze. Kierunki jego tworzenia, etyka literatury. Problem heroizacji. Problem pozbawionej heroizmu idealizacji. Problem typizacji. Problem relacji pomiędzy autorem i bohaterem. Obraz odgórny i sondowanie bohatera. Elementy i typy zwieńczania. Stopień urzeczowienia (resp. odgórności) obrazu bohatera. Stopień wolności (zasadniczej niezwieńczalności) obrazu bohatera. Niewspółobecność bohatera. Naiwna niewspółobecność (punkt widzenia „innego") w narracji pierwszoosobowej. Zneutralizowany obraz „ja” (opowieść o sobie jako o „innym”).

Gogol poczuwał się do wyjątkowej, specyficznie etycznej odpowiedzialności za bohatera, niezależnie od skrajnej odgórności jego obrazów. Właśnie ze względu na tę skrajną odgórność, uśmiercanie postaci w stwarzanych obrazach, pisarz wyostrzał problem ich ocalenia i przeobrażenia jako ludzi. Pokrewieństwo metody odgórnego zwieńczania obrazów i nadawania nazw-przezw. Zatracenie w przezwach pierwiastka kreatywnego, odradzającego.

Kłamstwo jest najbardziej współczesną i aktualną formą zła. Fenomenologia kłamstwa. Wyjątkowa różnorodność i wyrafinowanie jego form, przyczyny zdumiewającej aktualności. Filozofia kłamstwa. Kłamstwo retoryczne. Kłamstwo obrazu literackiego. Kłamstwo w formach powagi (związanych ze strachem, groźbą i przemocą). Nie wyłoniła się jeszcze taka forma siły (potęgi, władzy), która byłaby pozbawiona nieuniknionej domieszki kłamstwa. Ślepota na sens bytu idealnego (niezależnie od tego, czy się o nim wie, czy nie), sens sam w sobie. Reifikacja okłamywanego. To jedna $z$ form przemocy i uprzedmiotowienia człowieka. Legenda o Wielkim Inkwizytorze w nowym naświetleniu. Swiatowe znaczenie powieści Dostojewskiego. Historia typu takiej powieści. W jaki sposób kształtowały się specyficzne formy przedstawiania rzeczywistości i wnętrza człowieka. Strukturalno-kompozycyjna charakterystyka powieści. Fabuła i jej właściwości (prowokowanie, poddawanie próbie, sondowanie). Typ bohatera.

Analiza sposobów wyrażania powagi i ich bieguny (strach, groźba, litość, współczucie, smutek itp.). 
Dziewiętnastowieczny ateizm - prymitywny i płytki - nie zobowiązywał religii do niczego, można było nadal wierzyć „po staremu”. Nowe, kolejne przezwyciężenie naiwności. Określa ona wszystkie podstawy i przesłanki naszego myślenia i naszej kultury. Konieczność nowego, filozoficznego zdziwienia światem. Wszystko mogłoby przecież wyglądać inaczej. Trzeba przypomnieć sobie świat tak, jak wspomina się swoje dzieciństwo, kochać tak, jak można kochać tylko coś naiwnego (dziecko, kobietę, przeszłość).

Przełozyla Tamara Brzostowska 